\title{
MERANCANG STRATEGI BERSAING PT. VICTORY ROTTANINDO
}

\section{Shader Mubarak Arthamin, Anisa Shabrina dan Ananda Aldrin Toalu}

Universitas Airlanga Surabaya, Indonesia

Email: anshbrn@gmail.com, thegreatshader@gmail.com dan aldrin.toalu@gmail.com

\begin{tabular}{|c|c|}
\hline INFO ARTIKEL & ABSTRACK \\
\hline Dite & \multirow{11}{*}{$\begin{array}{l}\text { Platinum Victory Rottanindo is a company engaged in } \\
\text { the manufacture of rattan raw materials into furniture. } \\
\text { The company works with three distributors in the country } \\
\text { to export its products to the UK. But over time, the } \\
\text { company's sales in } 2016 \text { declined. By using PEST, five } \\
\text { porter forces and value chains to analyze external and, } \\
\text { internal factors aimed at understanding the company's } \\
\text { competitive position, conclusions can be drawn in the IE } \\
\text { matrix. Quadrant of PT. VR has a position at coordinate } \\
2,718 ; 2.27 \text { or cell V is in hold and Maintan state. In this } \\
\text { case, it is recommended that the company conduct } \\
\text { market penetration and product development strategies. } \\
\text { The purpose of this research is: internal and external } \\
\text { analysis of the industry's competitive environment, } \\
\text { analyzing the company's position in the external internat } \\
\text { matrix, and formulating the right competitive strategy for } \\
\text { PT. Victory Rottanindo. }\end{array}$} \\
\hline 12 Februari 2021 & \\
\hline Direvisi & \\
\hline 20 Februari 2021 & \\
\hline Dise & \\
\hline 15 Maret 2021 & \\
\hline Keywords: & \\
\hline Victory $12 q w 13$ & \\
\hline & \\
\hline $\begin{array}{l}\text { manufacturing industry; } \\
\text { marketing; furniture }\end{array}$ & \\
\hline & \\
\hline
\end{tabular}

\section{ABSTRAK}

PT. Victory Rottanindo adalah perusahaan manufaktur yang mengolah bahan baku rotan menjadi furniture. Perusahaan bekerja sama dengan tiga distributor di negara itu untuk mengekspor produknya ke Inggris. Namun seiring berjalannya waktu, penjualan perseroan pada 2016 menurun. Melalui analisis faktor eksternal dan internal, faktor-faktor tersebut dirancang dengan menggunakan PEST, kekuatan porter lima dan rantai nilai menentukan posisi kompetitif perusahaan dapat diringkas di kuadran matriks IE bahwa PT. VR memiliki posisi pada koordinat $2.718 ; 2.27$ atau baterai $\mathrm{V}$. yaitu pada kondisi Hold dan Maintan. Dalam hal ini, disarankan agar perusahaan melakukannya strategi

\section{Kata Kunci:}

PT. Victory12qw13 Rottanindo; industri manufaktur; marketing; mebel market penetration dan product development. Tujuan dari penelitian ini yaitu: menganalisis lingkungan persaingan industri secara internal dan eksternal, menganalisis posisi perusahaan dalam matriks internal deeheksternal, dan menyusun formulasi strategi bersaing yang tepat PT. Victory Rottanindo. 
Coresponden Author

Email: anshbrn@gmail.com

Artikel dengan akses terbuka dibawah lisensi

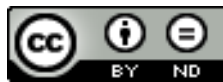

\section{Pendahuluan}

PT. Victory Rottanindo (selanjutnya disebut PT. VR) merupakan perusahaan yang bergerak di bidang pembuatan furniture (mebel) rotan dan aluminium rotan sintesis. Produk mebel PT. VR berupa kursi, meja, sofa, lemari, dan keranjang. Dalam scope bisnisnya, PT. VR menjual produknya secara ekspor ke negara Inggris berupa business to business (B2B) dengan perusahaan yang bergerak di bidang distribusi (selanjutnya disebut buyer). Saat ini, PT. VR memiliki tiga buyer yaitu; Daro, Cane Industries, dan Garden Funiture Center (GFC).

PT. VR didirikan pada tahun 2000 oleh Bapak Edward Low di Porong Sidoarjo. Awal mula perusahaan ini bergerak dibidang rotan adalah hubungan baik owner dengan salah satu pengusaha mebel di negara Inggris yaitu X Company. Kesuksesan dalam memenuhi order X Company kemudian dilirik oleh salah satu perusahaan yaitu Daro Ltd. Akhirnya, owner melayani dua buyer tersebut dan memiliki pangsa pasar yang sama yaitu kelas middle up namun desain produk yang dijual berbeda.

Seiring berjalannya waktu perusahaan ini terus berkembang hingga memiliki 200 pegawai termasuk buruh. Tiap tahunnya perusahaan mengirimkan lebih dari 50 kontainer ke Inggris. Kesuksesan melayani pasar Inggris, PT. VR kemudian mencoba ekspor ke negara Jepang dan Amerika Serikat. Namun masa kejayaan tersebut tahun demi tahun mulai surut karena beberapa buyer tidak melanjutkan order.

Pada tahun 2006, PT. VR memasuki masa terpuruknya. Pertama, di Kabupaten Sidoarjo mengalami bencana alam besar yaitu lumpur lapindo yang berdampak pada tenggelamnya pabrik PT. VR, sehingga berhenti beroperasi selama beberapa minggu. Kedua, salah satu buyer terbesar yaitu X Company yang mulai gulung tikar. Melihat kondisi tersebut, pemilik perusahaan mencari pabrik pengganti yang layak untuk berproduksi. Akhirnya pada bulan Juni tahun 2006, PT. VR secara resmi dipindahkan ke Jalan Kesatrian nomor 9, Kecamatan Buduran, Kabupaten Sidoarjo.

Proses pembelian produk mebel rotan dan aluminium PT. VR dimulai dengan penurunan Purchase Order (PO) oleh buyer. Dalam proses PO ini, buyer memesan sesuai dengan kebutuhannya tanpa minimum jumlah dan perusahaan hanya akan memproduksi barang ketika ada order. Sistem ini dinamakan dengan make to order (MTO). Selain itu, buyer juga dapat memesan produk berdasarkan desain yang diinginkan. Setelah PO diturunkan oleh buyer, kemudian PT. VR memesan bahan baku ke supplier dan selanjutnya melakukan proses produksi. Tahap terakhir adalah mengirimkan produk yang sudah jadi (finished good) melalui ekspedisi pelayaran sesuai dengan tujuan yang diminta buyer. 


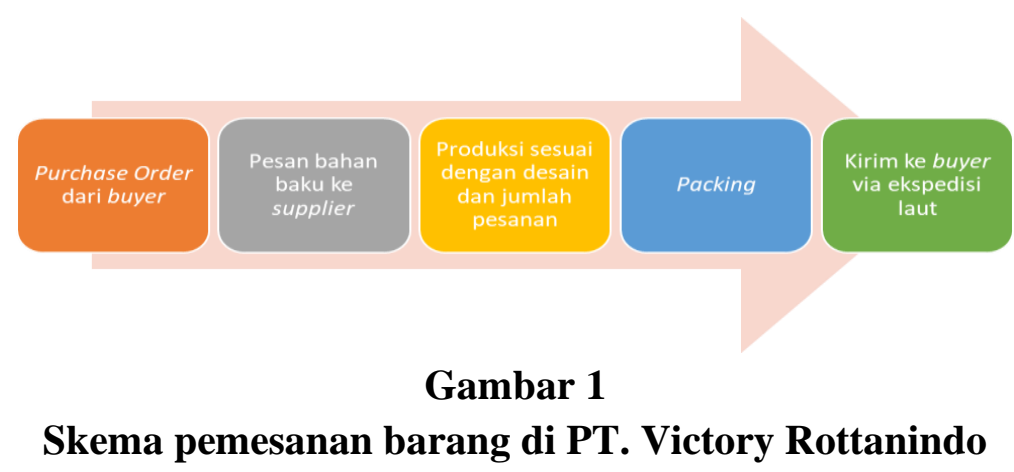

Analisis PEST (Politik, Ekonomi, Sosial, Teknologi) digunakan untuk menganalisis lingkungan eksternal, terutama lingkungan eksternal yang berkaitan dengan negara atau wilayah tempat perusahaan atau industri berada tersebut (Wheelen \& Hunger, 2012). Analisis Five Porter Forces merupakan kerangka analisis pengembangan strategi industri dan komersial 0020 dikembangkan oleh (Rozak, 2018). Berdasarkan lima model kekuatan Porter, lima hal dapat digunakan untuk mengetahui tingkat persaingan dan daya tarik pasar di industri (Wheelen \& Hunger, 2012). Sebuah industri dapat dikatakan tidak menarik bila kombinasi dari five forces dapat menurunkan profitabilitas industri tersebut. Sedangkan sebuah industri dapat dikatakan menarik apabila kombinasi dari five forces dapat meningkatkan profitabilitas atau menjanjikan untuk industri tersebut (Wheelen \& Hunger, 2012).

Analisis lingkungan internal dilakukan untuk mencocokkan kekuatan dan kelemahan internal perusahaan, terdapat peluang internal dan ancaman eksternal. (Setyorini \& Santoso, 2017). Sedangkan (D. Yulianti, 2014) Tunjukkan bahwa lingkungan internal adalah proses di mana rencana strategis akan memeriksa faktorfaktor internal perusahaan untuk menentukan perusahaan mana yang memiliki kelebihan dan kekurangan yang jelas sehingga mereka dapat secara efektif mengelola peluang dan merespon ancaman di lingkungan. Dalam proses ini, renstra akan mengkaji faktor internal perusahaan untuk menentukan dimana perusahaan memiliki kekuatan dan kelemahan yang jelas sehingga dapat secara efektif mengelola peluang dan merespon ancaman di lingkungan. Tool yang digunakan dalam menganalisis lingkungan internal perusahaan pada penelitian ini adalah analisis VRIO (Value, Rareness, Imitability, Well-Organized). Analisis VRIO digunakan untuk mengidentifikasi apakah sumber daya dan kapabilitas tertentu yang dimiliki perusahaan untuk menentukan kekuatan atau kelemahan (Tsai \& Lin, 2016). Melakukan analisis VRIO untuk mengetahui potensi perusahaan sehingga menjadikannya sebagai keunggulan kompetitif bagi perusahaan dan merumuskan strategi yang tepat berdasarkan kemampuan dinamis perusahaan untuk menyesuaikan situasi persaingan saat ini (Sirmon et al., 2007) (Ployhart \& Moliterno, 2011).

\section{Metode Penelitian}

Metode yang digunakan dalam penelitian ini adalah kualitatif, dan dapat digunakan untuk mencari dan memahami apa yang terjadi di balik suatu fenomena yang 
terkadang sulit untuk dipahami. Metode kualitatif mempertimbangkan beberapa hal, yaitu: studi kasus yang dipilih, bagaimana informasi dikumpulkan, serta jenis data yang digunakan. Penelitian kualitatif adalah proses penelitian yang memberikan deskripsi mendalam tentang pidato, tulisan, dan/tau perilaku yang dapat diamati dari individu, kelompok, komunitas, atau organisasi tertentu dan melakukan penelitian dari perspektif yang lengkap, komprehensif dan holistik (Rahmat et al., 2012). Metode kualitatif bertujuan untuk mendapatkan pemahaman umum tentang realitas sosial.

Pendekatan kualitatif membutuhkan pertanyaan penelitian atau research question yang dapat dirumuskan berdasarkan permasalahan pada penelitian (Carter \& Yeo, 2018). Pertanyaan yang dirumuskan harus jelas, terutama istilah dan teori yang digunakan peneliti harus didefiniskan dan diutarakan jika berasal dari interpretasi baru.

Metode kualitatif digunakan dalam penelitian ini karena fokus kegiatan penelitian ini adalah melihat kondisi nyata industri mulai dari ketersediaan sumber daya hingga dibeli oleh konsumen akhir yang kemudian disesuaikan dengan prinsip-prinsip dan penerapan konsep strategi bersaing pada PT. Victory Rottanindo. Penelitian ini akan menghasilkan teks tertulis dalam bentuk deskriptif sumber data primer maupun sekunder.

Jenis dari studi ini adalah studi kasus. Studi kasusnya adalah investigasi yang difokuskan pada menjelaskan, memahami, memprediksi dan/atau mengendalikan proses individu yang serupa, perseorangan, organisasi, grup, industri, budaya, negara, dll (Woodside \& Baxter, 2012). Sedangkan menurut (Fitrah, 2018), studi kasus adalah sebuah penyelidikan empiris yang melihat fenomena sementara di dunia sebenarnya di mana batas antara fenomena dan konteks tidak jelas.

\section{Hasil dan Pembahasan}

Kesuksesan perusahaan dalam meningkatkan penjualan salah satunya berasal dari hubungan baik dengan salah satu buyer yaitu Daro. Perusahaan telah bekerjasama dengan Daro selama 15 tahun hingga pergantian generasi kedua pada bisnisnya. Setiap tahun, Daro memiliki kontribusi order yang cukup banyak pada perusahaan utamanya produk mebel rotan. Di negara Inggris sendiri, Daro merupakan salah satu pemasok retailer besar yaitu Laura Ashley Ltd.

Penjualan PT. VR secara keseluruhan mulai tahun 2012 hingga 2015 terus meningkat dari produk mebel rotan maupun aluminium sintesis. Namun jika dilihat lebih detil, penjualan produk mebel rotan milik Daro mulai menurun pada tahun 2015 dan berkelanjutan di tahun 2016. Sedangkan, penjualan ke Cane Industries dan Garden Furniture Center terus meningkat sampai dengan tahun 2015 dan menurun pada tahun 2016. Tabel 1 di bawah Ini adalah data penjualan perusahaan lima tahun lalu (20122016). 


\section{Tabel 1}

Volume Penjualan PT. Victory Rottanindo Tahun 2012 - 2016

\begin{tabular}{lccccc}
\hline \multicolumn{1}{c}{ Buyer } & \multicolumn{5}{c}{ Tahun } \\
\cline { 2 - 6 } & 2012 & 2013 & 2014 & 2015 & 2016 \\
\hline $\begin{array}{l}\text { Cane } \\
\text { Industries }\end{array}$ & $\$ 18.230,00$ & $\$ 90.883,28$ & $\$ 61.452,52$ & $\$ 228.205,35$ & $\$ 219.290,51$ \\
\hline Daro & $\$ 738.830,05$ & $\$ 755.281,25$ & $\$ 841.936,29$ & $\$ 759.271,57$ & $\$ 631.537,92$ \\
\hline $\begin{array}{l}\text { Total } \\
\text { penjualan } \\
\text { rotan }\end{array}$ & $\$ 757.060,05$ & $\$ 846.164,53$ & $\$ 903.388,81$ & $\$ 987.476,92$ & $\$ 850.828,43$ \\
\hline $\begin{array}{l}\text { Garden } \\
\text { Furniture }\end{array}$ & $\$ 225.289,86$ & $\$ 238.325,31$ & $\$ 268.075,35$ & $\$ 311.610,36$ & $\$ 283.903,90$ \\
$\begin{array}{l}\text { Center } \\
\text { Total } \\
\text { penjualan } \\
\text { aluminium }\end{array}$ & $\$ 225.289,86$ & $\$ 238.325,31$ & $\$ 268.075,35$ & $\$ 311.610,36$ & $\$ 283.903,90$ \\
\hline $\begin{array}{l}\text { Total } \\
\text { penjualan } \\
\text { perusahaan }\end{array}$ & $\$ 982.349,91$ & $\$ 1.084 .489,84$ & $\$ 1.171 .464,16$ & $\$ 1.299 .087,28$ & $\$ 1.134 .732,33$ \\
\hline
\end{tabular}

\section{Sumber: Data Perusahaan}

Naik turunnya performansi perusahaan memang sangat bergantung pada penjualanya ke buyer. Sedangkan dari sisi buyer, permintaan produknya bergantung pada penjualan retailer kepada end customer di negara Inggris. Sehingga dapat disimpulkan bahwa faktor kesuksesan PT. VR ini sangat bergantung pada kondisi industri mebel di negara Inggris sendiri. Berikut adalah alur produk PT. VR hingga end customer.

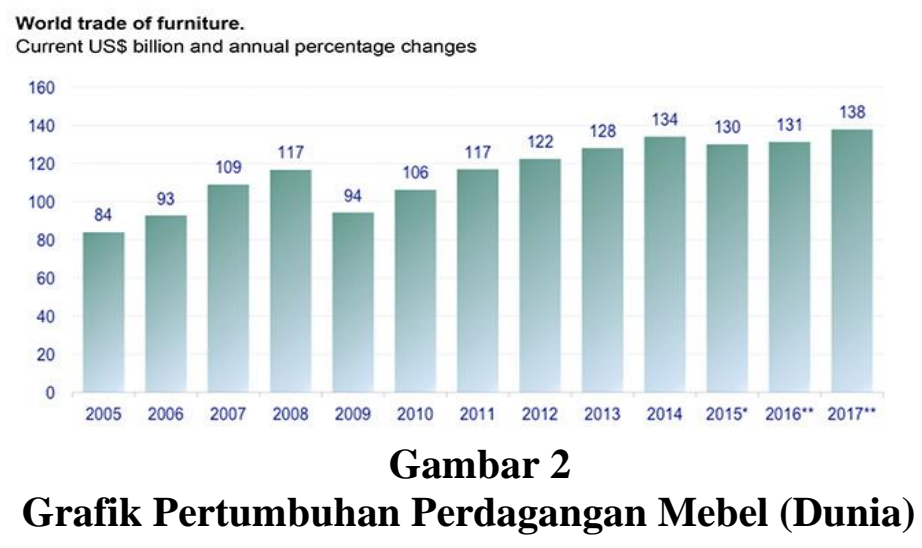

Amerika Serikat merupakan negara pengimpor mebel terbesar diikuti dengan negara Jerman, Perancis, Inggris, dan Kanada. Dari tahun 2009-2015, Amerika Serikat terus mengalami peningkatan impor dimana negara Inggris dan Kanada mengalami stagnan serta negara Jerman dan Perancis mengalami fluktuatif. Berikut merupakan grafik pertumbuhan negara-negara pengimpor mebel terbesar. 


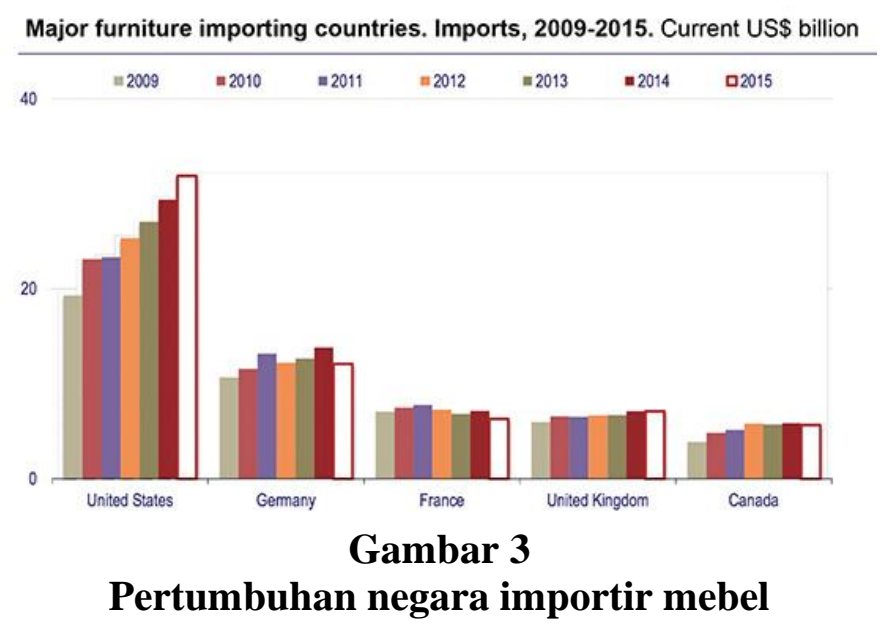

Sedangkan negara pengekspor mebel terbesar adalah Cina. Pertumbuhan ekspor mebel Cina tumbuh signifikan dari tahun 2009 hingga 2012, namun stagnan pada tahun 2014 dan tumbuh pada tahun 2015. Negara lain yang merupakan eksportir terbesar adalah Jerman, Itali, Polandia, dan Vietnam.

Tabel 2

Market Share Industri Mebel

\begin{tabular}{llccc}
\hline No & Nama Perusahaan & \multicolumn{2}{c}{ Tahun $(\mathbf{\%})$} & Perubahan \\
\cline { 3 - 4 } & & 2016 & 2017 & $(\mathbf{\%})$ \\
\hline $\mathbf{1}$ & IKEA & 6.3 & 5.7 & $-0,6$ \\
\hline $\mathbf{2}$ & DFS & 5.7 & 4.9 & $-0,8$ \\
\hline $\mathbf{3}$ & Steinhoff & 4.7 & 3.8 & $-0,9$ \\
\hline $\mathbf{4}$ & Argos & 3.6 & 4.3 & 0,7 \\
\hline $\mathbf{5}$ & John Lewis & 3.5 & 3.5 & 0 \\
\hline $\mathbf{6}$ & Nobia & 3.2 & 3.3 & 0,1 \\
\hline $\mathbf{7}$ & Oak Furniture Land & 1.5 & 2.0 & 0,5 \\
\hline $\mathbf{8}$ & B\&Q & 2.4 & 3.8 & 1,4 \\
\hline $\mathbf{9}$ & Wren & 2.3 & 1.8 & $-0,5$ \\
\hline $\mathbf{1 0}$ & ScS & 2.0 & 1.8 & $-0,2$ \\
\hline $\mathbf{1 1}$ & M\&S & 1.2 & 1.5 & 0,3 \\
\hline
\end{tabular}

Sumber: Mintel Ltd.

Sedangkan melihat perilaku pembelian masyarakat negara Inggris, berdasarkan data Mintel Group Ltd. per bulan Juli 2017 menunjukkan bahwa terdapat beberapa alasan utama mereka memilih toko ritel untuk berbelanja mebel. Pertama, toko ritel tersebut memiliki harga termurah. Kedua, pembeli dapat membeli melalui website toko tersebut atau mengakses website untuk melihat produk dan harga yang ada. Ketiga, toko ritel tersebut memiliki suasana yang nyaman. Keempat, karena toko tersebut memiliki showroom dan yang kelima karena pilihan yang ditawarkan cukup banyak. 


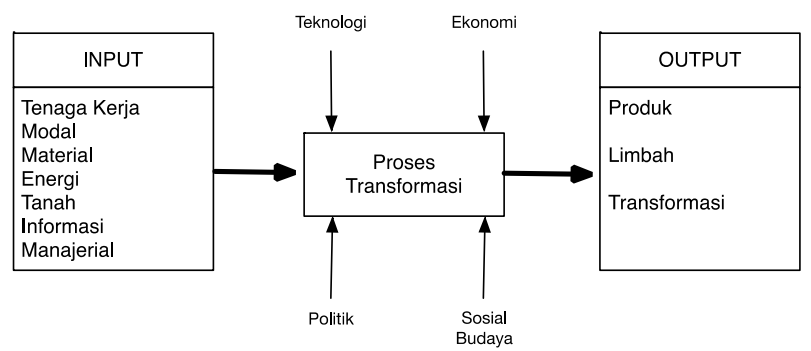

Gambar 4

Proses Produksi

Strategi dalam dunia militer diartikan sebagai sains dan seni dalam perintah militer yang dilakukan dari rencana keseluruhan dan melibatkan operasional sangat besar dalam dunia bisnis. Strategi didefinisikan suatu rencana yang menggabungkan antara tujuan perusahaan, peraturan, dan action plan secara bertahap (Hill et al., 2014). Sedangkan menurut Robert M. Grant, strategi adalah sebuah arti dimana individual atau organisasi mencapai tujuannya. Strategi fokus pada pencapaian tujuan yang pasti, yang termasuk alokasi sumber daya dan menunjukkan suatu konsistensi, integrasi, serta actions.

\section{Value}

Value jelaskan apakah sumber daya dan kapabilitas perusahaan memungkinkan perusahaan untuk menghadapi peluang dan ancaman yang ditimbulkan oleh lingkungan eksternal. Menjadi kekuatan, perusahaan harus bisa memanfaatkan peluang atau meminimalisir ancaman, begitu pula sebaliknya. (Wandrial, 2011) menjelaskan apabila sebagian besar jawaban atas pertanyaan ini adalah "ya", yang artinya perusahaan memiliki kemampuan dan upaya untuk memanfaatkan peluang dan menggunakan sumber daya yang dimilikinya untuk mengatasi ancaman yang ada. dalam kasus ini, perusahaan harus memahami sumber daya yang dimilikinya tidak selalu berharga, tetapi bergantung pada Pengembangan lingkungan internal dan eksternal perusahaan sendiri. Sumber daya dan kapabilitas perusahaan yang berharga di masa lalu tidak menjamin akan selalu demikian berharga. Preferensi pelanggan, perubahan struktur industri atau teknologi akan menurunkan nilai sumber daya dan kapabilitas perusahaan. Perusahaan yang tidak lagi memiliki sumber daya dan kemampuan yang berharga memiliki dua pilihan. Opsi pertama adalah mengembangkan sumber daya dan fungsi baru yang berharga. Kedua, gunakan keunggulan tradisional dengan cara baru (Wandrial, 2011).

2. Rare

Sumber daya dan kapabilitas perusahaan haruslah unik dan dapat digolongkan sumber daya yang jarang apabila yang memiliki hanya dua atau tiga perusahaan saja. Jika sumber daya dan kapabilitas yang dimiliki perusahaan berharga, tetapi juga dimiliki oleh banyak pesaing, jadi ini bukan keunggulan kompetitif (competitive advantage), ini hanya akan memberikan kesetaraan kompetitif (competitive parity). Dengan kata lain, karena banyak pesaing lain 
memiliki sumber daya yang sama, perusahaan hanya akan menikmati keuntungan rata-rata industrinya. Umumnya, selama jumlah perusahaan dengan sumber daya dan kapabilitas lebih sedikit daripada jumlah perusahaan di industri, sumber daya ini dapat diklasifikasikan sebagai sumber keunggulan kompetitif (Wandrial, 2011).

\section{Imitability}

Sumber daya yang tidak dimiliki perusahaan lain tersebut bermaksud untuk memiliki asetnya sendiri, namun mengalami kerugian biaya. Maka ini sangat berharga, nilai yang berharga tersebut jarang dimiliki oleh pesaing. Hal ini hanya sumber keunggulan kompetitif perusahaan (Wandrial, 2011). Jika Perusahaan memiliki sumber daya yang dapat digunakan sebagai sumber keunggulan kompetitif, dan pesaing lain dapat mencapai tujuan ini melalui dua opsi strategis. Pertama-tama, abaikan keunggulan kompetitif dan operasikan seperti biasa. Strategi ini tergolong murah karena tidak membutuhkan modal yang besar dan mudah, namun hanya dapat memberikan pendapatan di bawah rata-rata industri. Kedua, cobalah untuk memahami kesuksesan perusahaan dan salin sumber daya dan strategi yang ada. Jika pesaing tidak menghadapi kerugian biaya dalam situasi ini, strategi penggandaan sumber daya akan memberikan keunggulan kompetitif bagi industri yang dimiliki banyak perusahaan lain dalam industri tersebut.

Ada dua bentuk peniruan dari sumber itu sendiri, yaitu peniruan langsung atau mencari pengganti. Jika biaya penyalinan lebih besar daripada biaya membangun sumber daya ini sendiri, maka keunggulan kompetitif perusahaan dengan sumber daya yang berharga dan langka akan dipertahankan. Sebaliknya, jika biayanya sama, keunggulan kompetitif hanya akan diperoleh sementara.

Demikian pula, biaya untuk menemukan alternatif sumber daya ini juga tinggi. Ada empat alasan untuk situasi ini cost disadvantage, yaitu sejarah perusahaan yang unik sehingga ia memiliki sumber daya yang valuable dan jarang (unique historical conditions), kurangnya pemahaman pesaing tentang hubungan antara sumber daya dan keunggulan kompetitif mereka (causal ambiguity), kompleksitas kondisi sosial yang menjadikan sumber daya sebagai keunggulan kompetitif (social complex), serta adanya hak paten dan kepemilikan perusahaanperusahaan tersebut di atas sumber daya tersebut.

4. Well-Organized

Komponen ini biasa disebut complementary resources and capabilities. Sumber daya dan kapabilitas perusahaan bukanlah keunggulan kompetitif apabila berdiri sendiri, namun jika dikombinasikan dan diorganisir dengan baik akan memungkinkan perusahaan menyadari potensi penuh atas keunggulan kompetitif. Beberapa contoh bentuk organisir yang dapat dilakukan perusahaan adalah struktur pelaporan formal, sistem kontrol manajemen yang eksplisit, dan kebijakan kompensasi (Wandrial, 2011). 


\section{EFAS dan IFAS Matrix}

Matriks IF (Wheelen \& Hunger, 2012) jelaskan matriks EFAS atau External Strategic Factor Analysis Summary adalah alat untuk mencatat dan mengevaluasi ancaman dan peluang di luar perusahaan. Matriks EFAS digunakan untuk mengidentifikasi dan mengevaluasi hubungan antara ancaman dan peluang dalam kondisi aktual saat ini.

AS atau Internal Strategic Factor Analisis Summary merupakan alat untuk mengevaluasi dan membuat daftar keuntungan secara singkat (strength) dan kelemahan (weakness) berada di lingkup internal perusahaan. Matriks juga digunakan sebagai dasar untuk mengidentifikasi dan mengevaluasi hubungan strength dan weakness realitas terjadi dilapangan dalam organisasi (Wijaya, 2013). Berdasarkan pendapat (Wheelen \& Hunger, 2012) Matriks EFAS dan IFAS dibagi menjadi lima tahap, yaitu:

1. Kolom 1 (Faktor strategis). Buat daftar item dari masing-masing EFAS dan IFAS yang paling penting meliputi kekuatan (strength), kelemahan (weakness), peluang (opportunity) dan ancaman (threat).

2. Kolom 2 (Weight). Berikan timbang setiap faktor strategis. Bobot digunakan sebagai indikator dari kepentingan relatif suatu faktor untuk kesuksesan perusahaan di industri. Faktor yang paling berpengaruh diberikan bobot paling tinggi, begitu pula sebaliknya. Jumlah total bobot yang ditetapkan ke semua faktor harus sama dengan 1.0 sehingga pemberiaan bobot untuk masing-masing faktor strategis harus disesuaikan. Angka yang diberikan mulai dari 0,0 (tidak penting) hingga 1,0 (paling penting).

3. Kolom 3 (Rating). Berikan peringkat (rating) setiap faktor strategis yang menunjukkan faktor-faktor tersebut menunjukkan kelemahan atau kekuatan perusahaan, dan ancaman atau peluang perusahaan. Nomor yang diberikan berkisar dari 5,0 (outstanding) hingga 1,0 (poor) Perlu dicatat bahwa peringkat didasarkan pada perusahaan, dan bobot didasarkan pada industrinya.

4. Kolom 4 (Weighted Score). Kalikan Setiap bobot terkait dengan peringkatnya untuk menentukan nilai rata-rata setiap variabel.

5. Jumlahkan setiap variabel menentukan nilai yang diperoleh dengan total nilai tertimbang organisasi. Rentang rata-rata tertimbang total adalah di antara 1,0 (terendah) dan 4,0 (tertinggi), dengan rata-rata 2,5. Nilai rata-rata tertimbang total di bawah 2,5 menunjukkan organisasi internal yang lebih lemah, sedangkan organisasi dengan skor total lebih tinggi dari 2,5 menunjukkan kesehatan internal yang baik.

\section{Internal-External Matrix}

Internal-External Matrix yang selanjutnya disebut IE Matrix merupakan salah satu alat yang digunakan untuk menentukan rekomendasi strategis yang dapat digunakan dalam organisasi (Wheelen \& Hunger, 2012). Setelah pembobotan dengan EFAS dan IFAS Matrix, maka akan diketahui total weigthed score. Total weighted score tersebut selanjutnya dimasukan ke dalam IE Matrix untuk melihat letak perusahaan di kuadran matriks IE, dan tentukan rekomendasi 
strategi yang benar yang cocok untuk operasi perusahaan. Total weighted score pada IFAS adalah nilai pada sumbu $\mathrm{x}$, sedangkan total weighted score pada EFAS adalah nilai pada sumbu $y$.

Pada sumbu x yang ada di IE Matrix, total weighted score IFAS yang menunjukkan nilai 1.0 hingga 1.99 mewakili posisi internal yang lemah, nilai 2.0 hingga 2.99 mewakili posisi internal yang tergolong medium, dan nilai 3.0 hingga 4.0 adalah posisi yang kuat. Demikian pula degan sumbu y, total weighted score EFAS yang menunjukkan nilai 1.0. Nilai maksimum 1,99 menunjukkan posisi eksternal yang lemah, nilai 2,0 hingga 2,99 adalah sedang, dan nilai 3,0 hingga 4,0 menunjukkan posisi eksternal yang kuat.

Matriks IE dibagi menjadi tiga bidang besar dengan signifikansi strategis yang berbeda. Proses pembelahan sel I, II atau IV untuk pertama kalinya dapat digambarkan sebagai pertumbuhan dan konstruksi. Strategi penguatan (penetrasi pasar, pengembangan pasar dan pengembangan produk) dan integrasi (integrasi ke belakang, integrasi ke depan dan integrasi horizontal) berlaku untuk sektor ini. Bagian kedua yang terbagi menjadi sel III, V atau VII dapat digambarkan sebagai tahan dan tahan. Penetrasi pasar dan strategi pengembangan produk, apakah dua strategi umum yang digunakan oleh departemen. Bagian ketiga dibagi menjadi sel VI, VIII atau IX yaitu harvest or divest. Sebuah perusahaan yang berhasil dapat mencapai kombinasi bisnis yang terletak di dalam atau di sekitar Unit I pada IE Matrix. IE Matrix diilustrasikan pada Gambar 5.

\section{Teori Diversifikasi}

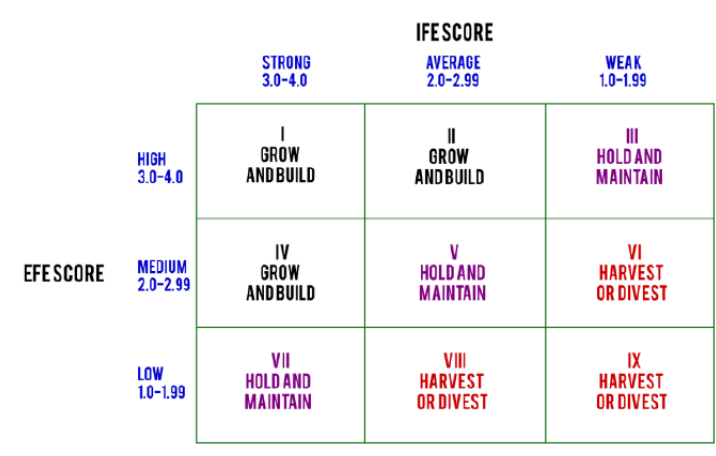

\section{Gambar 5}

\section{Internal-External Matrix}

Diversifikasi adalah membagi resiko suatu usaha di tempat yang berbeda. Sedangkan definisi diversifikasi perusahaan menurut (Scur \& de Queiroz, 2017) yaitu aktivitas bisnis baru yang terlibat dalam produk dan pasar baru. Diversifikasi mulai ramai dilakukan perusahaan pada awal abad ke 20 dengan alasan dua hal yaitu untuk tumbuh dan mengurangi resiko. Jika perusahaan dalam keadaan stagnan atau menurun pada industrinya, diversifikasi merupakan strategi yang dapat diterapkan perusahaan apalagi jika melalui akuisisi. Tujuan mengurangi resiko saat ini menarik siapa saja yang dapat menikmati keuntungan dari 
mengelola perusahaan lebih stabil. Shareholder dapat membagi resiko dengan cara diversifikasi portofolio.

Diversifikasi menurut (Wheelen \& Hunger, 2012) dibagi menjadi tiga yaitu; concentric, horizontal dan conglomerate. Diversifikasi concentric adalah menambahkan aktifitas bisnis baru yang masih berelasi pada aktifitas bisnis perusahaan saat ini. Hasil dari diversifikasi ini bisa berupa akuisisi yang sesuai dengan kebutuhan atas aset perusahaan seperti teknologi, aset, distribusi, sumber daya, dan produk (Hamidizadeh \& Taheri, 2013). Untuk mencapai diversifikasi concentric yang efektif, perusahaan harus memahami kekuatan dan kenunikan asetnya serta posisi strategi.

Menambahkan produk atau jasa baru yang tidak berhubungan dengan aktifitas bisnis perusahaan untuk konsumen saat ini (eksisting) disebut dengan diversifikasi horizontal. Strategi ini tidak terlalu beresiko bagi perusahaan karena sudah mengetahui konsumennya saat ini. Tujuan dari strategi ini adalah membentuk suatu nilai dari perusahaan. Tujuan tersebut dapat dicapai dengan cara menguatkan posisi persaingan masing-masing unit bisnis. Untuk mencapai diversifikasi horizontal agar efektif, beberapa hal harus diperhatikan perusahaan:

1. Ketika pemasukan diturunkan dari organisasi akan meningkat siginfikan dengan menambahkan produk atau jasa yang tidak berelasi

2. Ketika organisasi berkompetisi pada persaingan industri yang tinggi atau industri yang stagnan, adalah indikasi bahwa margin profit industri lemah

3. Ketika chanel distribusi dapat digunakan pada produk atau jasa yang baru

Menambahkan produk atau jasa baru yang tidak berhubungan dengan aktifitas bisnis perusahaan untuk konsumen baru disebut dengan diversifikasi conglomerate, strategi ini memiliki nilai yang lebih besar dibandingkan diversifikasi concentric (Widharta, 2013). Adapun beberapa cara agar diversifikasi conglomerate ini efektif diterapkan:

1. Ketika organisasi memiliki modal dan SDM yang dibutuhkan cukup memadai dalam berkompetisi di industri baru

2. Ketika organisasi memiliki kesempatan untuk membeli bisnis yang tidak berelasi yang merupakan kesempatan invetasi menarik

3. Ketika pasar eksisting saat ini untuk organisasi dianggap jenuh

Dalam mencapai strategi diversifikasi, perusahaan dapat menggunakan beberapa cara yang biasanya disebut usaha patungan, akuisisi dan merger. Usaha patungan adalah dua perusahaan yang sepakat untuk membentuk suatu perusahaan dengan skema saham 50\%:50\%. Sedangkan akuisisi adalah membeli suatu perusahaan oleh perusahaan lainnya yang terakhir adalah akuisisi yaitu dua perusahaan atau lebih yang menggabungkan untuk membentuk perusahaan baru.

Pasal 22 Pernyataan Standar Akuntansi Keuangan (PSAK) mengatur bahwa akuisisi adalah bentuk pihak pengakuisisi yang mengambil alih kepemilikan 
perusahaan (acquirer), Ini akan menghasilkan transfer kendali atas pihak yang dibeli. Kontrol atas perusahaan adalah:

a. Merumuskan kebijakan keuangan dan operasi perusahaan

satu jenis.

b. Tidak dikelola

c. Dapatkan suara mayoritas pada rapat dewan

Perbedaan antara akuisisi dan merger menyebabkan pihak lain dibubarkan sebagai badan hukum. Perusahaan yang terlibat dalam akuisisi tersebut masih ada didirikan sesuai dengan hukum dan beroperasi secara independen, namun pihak pengakuisisi telah melakukan transfer.

Sedangkan Pada saat penggabungan, pihak yang menerima penggabungan atau pihak yang menerima penggabungan disebut perusahaan yang menerima penggabungan atau pihak yang mengeluarkan saham (perusahaan penerbit). Pada saat yang sama, perusahaan yang berhenti dan bubar setelah penggabungan disebut perusahaan konsolidasi. Karena semua aset dan kewajiban dari perusahaan gabungan dipindahkan ke perusahaan yang bertahan, perusahaan yang bertahan secara otomatis akan bertambah besar. Perusahaan hasil merger akan menyerahkan status hukumnya sebagai entitas independen, dan status gabungan akan diubah menjadi bagian dari perusahaan yang menerima penggabungan (unit bisnis). Oleh karena itu, perusahaan hasil merger tidak dapat bertindak secara hukum atas namanya.

Analisis Value Chain adalah serangkaian aktivitas penciptaan value mulailah dengan bahan mentah asalnya supplier, beralih pada serangkaian aktivitas dalam menciptakan value-added yang terdiri dari proses produksi dan kegiatan memasarkan produk atau layanan sampai distributor mengirimkan produk akhir ke konsumen akhir (Gambar 6). Analisis Value Chain berfokus pada pengujian rantai pasok perusahaan secara keseluruhan dalam rangka menciptakan value.

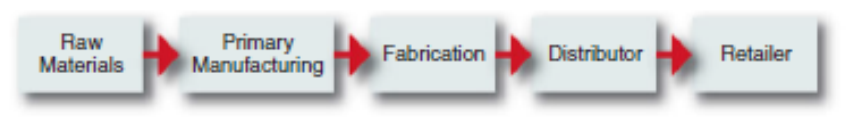

\section{Gambar 6}

Value Chain untuk Produk Manufatur

Porter dalam (Wheelen \& Hunger, 2012) mengusulkan agar kegiatan utama perusahaan manufaktur dapat dimulai dengan inbound logistic (penanganan bahan baku dan pergudangan), melalui proses operasional dimana pada tahap ini adalah tahapan mengolah bahan baku menjadi produk, dan berlanjut ke outbound logistic (pergudangan dan distribusi), selanjutnya yaitu kegiatan pemasaran dan penjualan produk pada konsumen, dan tahap akhir adalah kegiatan after sales atau melayani konsumen (instalasi, perbaikan, dan penjualan suku cadang). Value chain tidak akan berhasil apabila tidak adanya dukungan. Beberapa kegiatan pendukung, 
seperti pengadaan (purchasing), pengembangan teknologi (R\&D), manajemen sumber daya manusia, dan infrastruktur perusahaan (akuntansi, keuangan, perencanaan strategis), memastikan bahwa aktivitas utama value chain beroperasi secara efektif dan efisien. Masing-masing lini produk perusahaan memiliki value chain tersendiri, karena kebanyakan perusahaan membuat beberapa produk atau layanan yang berbeda, maka dalam analisis internal perusahaan juga melibatkan analisis value chain yang berbeda. Pemeriksaan sistematis terhadap value chain perusahaan dapat menghasilkan pemahaman yang lebih baik tentang kekuatan dan kelemahan internal yang dimiliki perusahaan untuk mendapatkan sumber keunggulan kompetitif.

Lingkungan luar organisasi dibedakan menjadi dua jenis, yaitu lingkungan makro dan lingkungan mikro (E. Yulianti \& Putra, 2014). (E. Yulianti \& Putra, 2014) lingkungan eksternal suatu organisasi diyakini dapat dibedakan menjadi dua jenis, yaitu lingkungan makro dan lingkungan mikro.

1. Lingkungan makro

Lingkungan makro adalah lingkungan umum yang dapat mempengaruhi seluruh industri, termasuk dalam lingkungan makro yaitu: politik, ekonomi, sosial, dan teknologi yang pada penelitian ini dianalisis menggunakan analisis PEST.

2. Lingkungan mikro

Lingkungan makro dapat juga disebut sebagai lingkungan indusri atau lingkungan kompetitif. Lingkungan mikro memiliki jarak lebih dekat dengan perusahaan sehingga dapat memberikan pengaruh langsung terhadap organisasi atau perusahaan. Dalam penelitian ini lingkungan makro atau lingkungan industri dianalisis menggunakan Five Porter Forces.

Daya tawar pembeli yang rendah akan menjadi peluang bagi (Hill et al., 2014).

Daya tawar pembeli dapat dikatakan tinggi apabila:

- Jumlah industri sangat banyak, tetapi pembeli sedikit

- Pembeli bersifat sensitif terhadap harga dan value yang diberikan oleh perusahaan

- Tersedia banyak alternatif produk subtitusi

- Switching cost rendah, misalnya untuk berpindah membeli produk lain tidak membutuhkan uang yang sangat tinggi sehingga menyebabkan pembeli tidak loyal pada suatu perusahaan

- Kuantitas produk yang dipesan konsumen

- Kualitas produk tidak penting bagi pembeli

- Pembeli memiliki informasi lengkap, misalnya: informasi tentang permintaan, harga pasar dan biaya produksi yang dilaksanakan perusahaan.

Perusahaan di beberapa industri bersaing secara agresif pada segi keuangan hingga tidak jarang menyebabkan tingkat kerugian perusahaan meningkat. Pada industri lainnya, persaingan pada segi keuangan diredam dan persaingan berfokus pada periklanan, inovasi, dan dimensi non-keuangan lainnya (Grant, 2016). Jika kekuatan persaingan antar perusahaan sejenis lemah, perusahaan ada peluang untuk menaikkan 
harga dan memperoleh keuntungan yang lebih besar. Tetapi jika persaingan antar perusahaan sejenis kuat, termasuk dalam hal persaingan harga dapat mengakibatkan persaingan yang ketat (Hill et al., 2014).

\section{Kesimpulan}

PT. Victory Rottanindo (PT. VR) merupakan perusahaan manufaktur mebel rotan dan mengekspor produknya ke negara Inggris. PT. VR memiliki beberapa buyer sebagai "middle man" seperti Cane Industries, Daro, dan Garden Furniture Center dimana perusahaan sangat ketergantungan distributor tersebut. Dalam kurun waktu lima tahun terakhir, PT. VR mengalami fluktuasi penjualan sehingga perlu untuk mengetahui posisi perusahaan dan merancang stategi bisnisnya. Penelitian ini menggunakan Internal External Matrix sebagai acuan dalam penelitian ini. Berdasarkan dari hasil analisa dan pembahasan maka didapatkan hasil analisis dengan menggunakan External Factor Evaluation (EFE) diperoleh skor perkalian antara bobot dan peringkat sebesar 2,27 dalam skala 2,99 dan dikategorikan sebagai medium. Sedangkan hasil analisis dengan menggunakan Internal Factor Evaluation (IFE) diperoleh skor perkalian antara bobot dan peringkat sebesar 2,718 dalam skala 2,99 dan dikategorikan sebagai average. Dengan menggunakan Matriks IE menganalisis lokasi PT. VR ada dalam koordinat $(2,718 ; 2,27)$, yang ada di dalam sel (hold and maintain). Dalam mempertahankan dan mempertahankan posisi ini, disarankan agar perusahaan menggunakan strategi penetrasi pasar dan pengembangan produk. 


\section{BIBLIOGRAFI}

Carter, S., \& Yeo, A. C.-M. (2018). Internet-enabled collective intelligence as a precursor and predictor of consumer behaviour. Economics, Management and Financial Markets, 13(4), 11.

David, F. R. (1997). Instructor's Manual with Test Item File, Strategic Management,[Fred R. David]. Prentice-Hall.

Fitrah, M. (2018). Metodologi penelitian: penelitian kualitatif, tindakan kelas \& studi kasus. CV Jejak (Jejak Publisher).

Grant, R. M. (2016). Contemporary strategy analysis: Text and cases edition. John Wiley \& Sons.

Hamidizadeh, M. R., \& Taheri, M. (2013). A comprehensive literature review in competitive advantages of businesses. Asian Journal of Research in Marketing, 2(6), 76-97.

Hill, C. W. L., Jones, G. R., \& Schilling, M. A. (2014). Strategic management: theory: an integrated approach. Cengage Learning.

Ployhart, R. E., \& Moliterno, T. P. (2011). Emergence of the human capital resource: A multilevel model. Academy of Management Review, 36(1), 127-150.

Rahmat, M. F., Salim, S. N. S., Sunar, N. H., Faudzi, A. M., Ismail, Z. H., \& Huda, K. (2012). Identification and non-linear control strategy for industrial pneumatic actuator. International Journal of Physical Sciences, 7(17), 2565-2579.

Rozak, S. (2018). TA: Perencanaan Strategi Sistem dan Teknologi Informasi pada RS. Damian Lewoleba dengan Pendekatan Ward and Peppard. Institut Bisnis dan Informatika Stikom Surabaya.

Scur, G., \& de Queiroz, R. P. (2017). The impact of diversification in the operations of strategy of capital goods companies. Gest. Prod., Sao Carlos, 24(2), 206-220.

Setyorini, H., \& Santoso, I. (2017). Analisis Strategi Pemasaran Menggunakan Matriks SWOT dan QSPM (Studi Kasus: Restoran WS Soekarno Hatta Malang). Industria: Jurnal Teknologi Dan Manajemen Agroindustri, 5(1), 46-53.

Sirmon, D. G., Hitt, M. A., \& Ireland, R. D. (2007). Managing firm resources in dynamic environments to create value: Looking inside the black box. Academy of Management Review, 32(1), 273-292.

Tsai, P., \& Lin, C. (2016). Creating a business strategy evaluation model for national museums based on the views of curators. Curator: The Museum Journal, 59(3), 287-303. 
Wandrial, S. (2011). Strategic Management Dan Strategic Leadership: Dua Sisi Mata Uang Kemampuan Untuk Hadapi Tantangan Perubahan Lingkungan Yang Drastis. Binus Business Review, 2(1), 415-422.

Wheelen, T. L., \& Hunger, J. D. (2012). Concepts in strategic management and business policy: Toward global sustainability. Pearson.

Widharta, W. P. (2013). Penyusunan strategi dan sistem penjualan dalam rangka meningkatkan penjualan toko damai. Jurnal Strategi Pemasaran, 1(2), 1-15.

Wijaya, M. H. P. (2013). Promosi, Citra Merek, Dan Saluran Distribusi Pengaruhnya Terhadap Keputusan Pembelian Jasa Terminix Di Kota Manado. Jurnal EMBA: Jurnal Riset Ekonomi, Manajemen, Bisnis Dan Akuntansi, 1(4).

Woodside, A. G., \& Baxter, R. (2012). Case study research in business-to-business contexts: Theory and methods. In Handbook of Business-to-Business Marketing. Edward Elgar Publishing.

Yulianti, D. (2014). Analisis Lingkungan Internal Dan Eksternal Dalam Pencapaian Tujuan Perusahaan. Jurnal Sosiologi, 16(2).

Yulianti, E., \& Putra, I. (2014). Perancangan Aplikasi Customer Relationship Management (CRM) pada English Language School (ELS) dengan Bahasa Pemrograman PHP. Jurnal Momentum ISSN 1693-752X, 16(1). 